\title{
ACUTE EFFECT OF SELF-MYOFASCIAL RELEASE EXERCISE VOLUME TO VERTICAL JUMP PERFORMANCE AND FLEXIBILITY IN WELL-TRAINED WOMEN VOLLEYBALL PLAYERS ${ }^{1}$
}

\section{IYYI ANTRENMANLI BAYAN VOLEYBOLCULARDA KENDI KENDİNE UYGULANAN MYOFASİAL GEVŞETME EGZERSIZ SÜRESININ DİKEY SIÇRAMA PERFORMANSI VE ESNEKLIK ÜZERINE AKUT ETKISİ}

\author{
İsa SAĞIROĞLU ${ }^{1}$, Serpil SALI ALI ${ }^{2}$, Osman ATEŞ ${ }^{3}$, Cem KURT $T^{1}$ \\ ${ }^{1}$ Department of Coaching Education, Trakya University, Edirne / Turkey \\ ${ }^{2}$ Department of Physical Education and Sport, Trakya University, Edirne / Turkey \\ ${ }^{3}$ Department of Sports Health, Istanbul University Faculty of Sports Sciences, Istanbul / Turkey
}

ORCID ID: 0000-0003-1436-9960', 0000-0002-5619-652X', 0000-0002-2992-8465', 0000-0002-0254-5923 ${ }^{1}$

Öz: Amaç: Bu çalışmanın amacı, kendi kendine uygulanan farklı süreli (30 saniye-60 saniye) miyofasiyal gevşetme egzersizlerinin alt ekstremite esneklik ve dikey sıçrama performansı üzerine akut etkilerinin incelenmesidir. Yöntem: Çalışmaya aynı takımda oynayan 18 bayan voleybolcu katılmıştır. Sporculara, 48 saat arayla, randomize crossover çalışma deseni kullanılarak, kontrol, 30 ve 60 saniye süreli foam roller egzersizi olacak şekilde üç farklı uygulama yaptırıldı. Her uygulamanın sonrasında sporculara esneklik (S\&R) ve yaylanarak sıçrama testi (CMJ) uygulandı. Bulgular: Araştırmanın sonuçları incelendiğinde, üç uygulama arasında istatistiksel bir farka rastlanmadı $(\mathrm{p}>0.05)$. Sonuç: Sonuç olarak, hem 30 hem de 60 saniye süreli foam roller egzersizlerinin benzer etkiye sahip olduğu ve kontrol grubuyla karşılaştırıldığında esneklik ve dikey sıçrama performansı üzerinde olumsuz bir etkiye sahip olmadığı görüldü. Bu sebeple, foam roller ile yapılan self-miyofasiyal gevşetme egzersizleri antrenman ya da yarışmalardan önce alternatif ısınma aracı olarak sporcular tarafindan kullanılabilir.

Anahtar Kelimeler: Voleybol, Foam Roller, Selfmiyofasiyal Gevşetme, Dikey Sıçrama, Esneklik
Abstract: Aim: The aim of this study is to analyze the acute implications of myofascial releasing exercises with alternating periods (30-60 seconds) of self-training on the flexibility of lower extremity and vertical jump performance. Method: 18 female volleyball players playing in the same team participated in this study. The athletes were asked to take part in three different exercise routines as control, 30 and 60 seconds with the foam roller with 48 hours between each session using a random crossover design. At the end of each session, the athletes were tested on flexibility (S\&R) and jumping performance (CMJ). Results: The results of the study have shown that there was no statistical difference between the three routines ( $p>0.05$ ). Conclusion: In conclusion, both the 30 -second and the 60 -second foam roller exercises yielded similar effects, and when compared to the control group no negative effects regarding flexibility and vertical jumping performance were observed. For this reason, foam roller exercises can be used as an alternative warm-up method by athletes both before training sessions and competitions.

Key Words: Volleyball, Foam Roller, Myofascial Releasing, Vertical Jump, Flexibility.

Doi: $10.17363 /$ SSTB.2017.4.5

(1) Corresponding Author: İsa SARIOĞLU, Department of Coaching Education, Trakya University, Edirne, Turkey, isagiroglu83@gmail.com, Received: 10.09.2017, Accepted: 14.12.2017, Type ofarticle (Research -Application) Conflict of Interest: None / Ethics "Yes Ethics Committee" "Trakya University, Faculty of Medicine Dean, Scientific Research Ethics Board, Issue:19/16 Date: 23.11.2016 


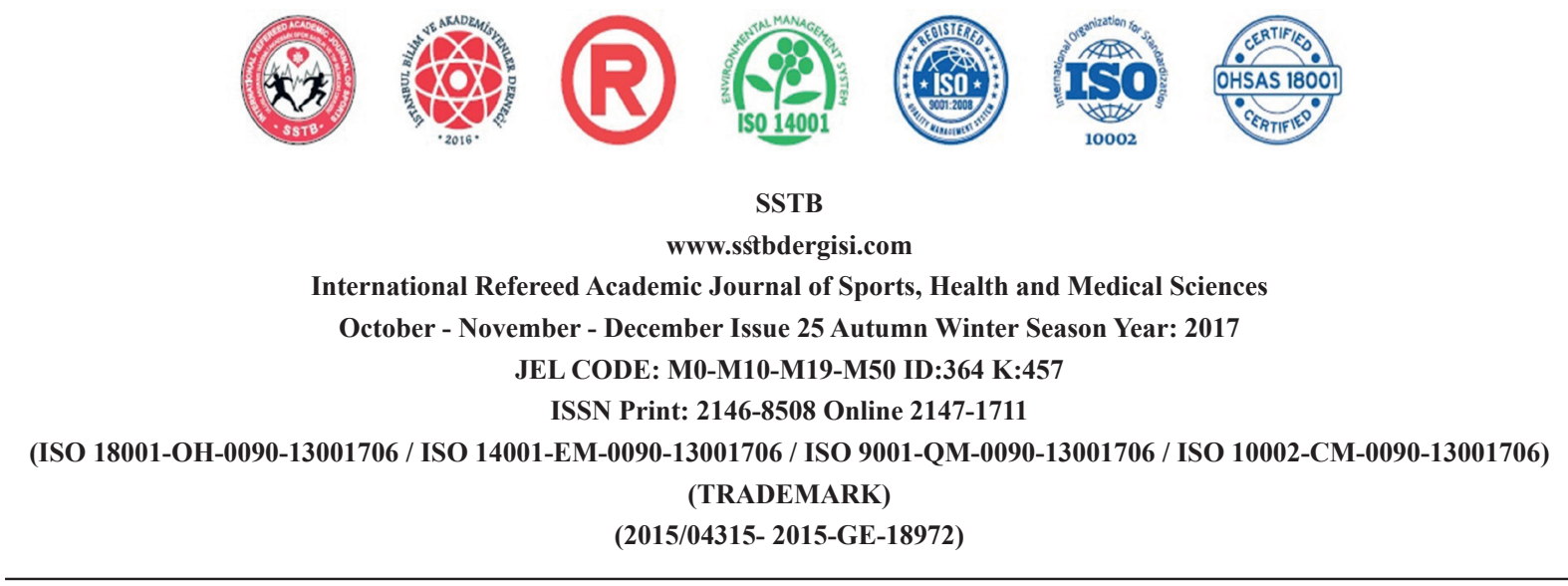

\section{INTRODUCTION}

In recent years, research studying the effects of different warm-up protocols on flexibility and athletic performance is rapidly increasing. These studies usually examine static stretching, dynamic stretching, mobility and self-miyofascial release (SMR) exercises (Beckett et. al, 2009: 445; Behm and Chaouachi, 2011:2636; Cramer et al., 2004; Fama and Bueti, 2011; Franco, et al., 2012: 2; Herda, et al., 2008: 810; Janot et al, 2012: 426; Joorkesh, 2007: 886; Marek, et al., 2007: 94; Keskin and Ates, 2016: 2). Particularly SMR exercises have been frequently used by athletes as an alternative warm-up technique due to their effects on the facia (Beardsley and Skarabot, 2015: 748). Regular exercise and performance create micro traumas in muscle tissue. These micro traumas cause damage in the facia over time, consequently leading to the loss of movement (Curran, et al., 2008: 433). Fascia is defined as a fibrous-collagen tissue that is part of the body's tensional force transmission system (Benjamin, 2009: 3). SMR exercises are among miyofascial release (MR) techniques. MR is a broad term used for manual therapy techniques applied by the therapists for many years to reduce fibrosis adhesions between the layers of fascia by applying pressure on the muscle and fascia (McKenney, Elder, Elder, \& Hutchins, 2013). Fibrous adhesion is known as painful condi- tions that prevent normal muscle mechanics (Curran et al., 2008: 433). Fibrous adhesions usually occur when the fascia loses its elasticity and stiffens as a result of such conditions as disease, injury and inactivity (MacDonald et al., 2013: 814).

Athletes perform self-MR technique using various tools during SMR exercises. Foam roller equipments are among the most frequently used tools (Healey, et al., 2014: 62; MacDonald et al., 2013: 813; Peacock et al., 2015: 2311 ). Foam roller exercises have many acute and chronic effects. The best known are acute and chronic increase in flexibility, decrease in muscle pain, modulation of autonomic nervous system activity, and arterial and vascular endothelial function effects (Beardsley and Skarabot, 2015: 748; MacDonald et al., 2013: 813; Peacock, et al., 2014: 203). Although SMR exercises have many positive impacts, there is no clear consensus on the mechanisms of action. Studies are focused on the mechanisms of action on the fascia, yet there is not much clear information yet. Simmonds, et al. (2012) examined the mechanism of SMR exercises in two categories: mechanical and neurophysiological effects. Mechanical effects include thixotropy, piezoelectric, facial adhesions, cellular responses, myofascial trigger points and facial inflammation. Neurphysiological effects are related to the Golgi tendon organ 


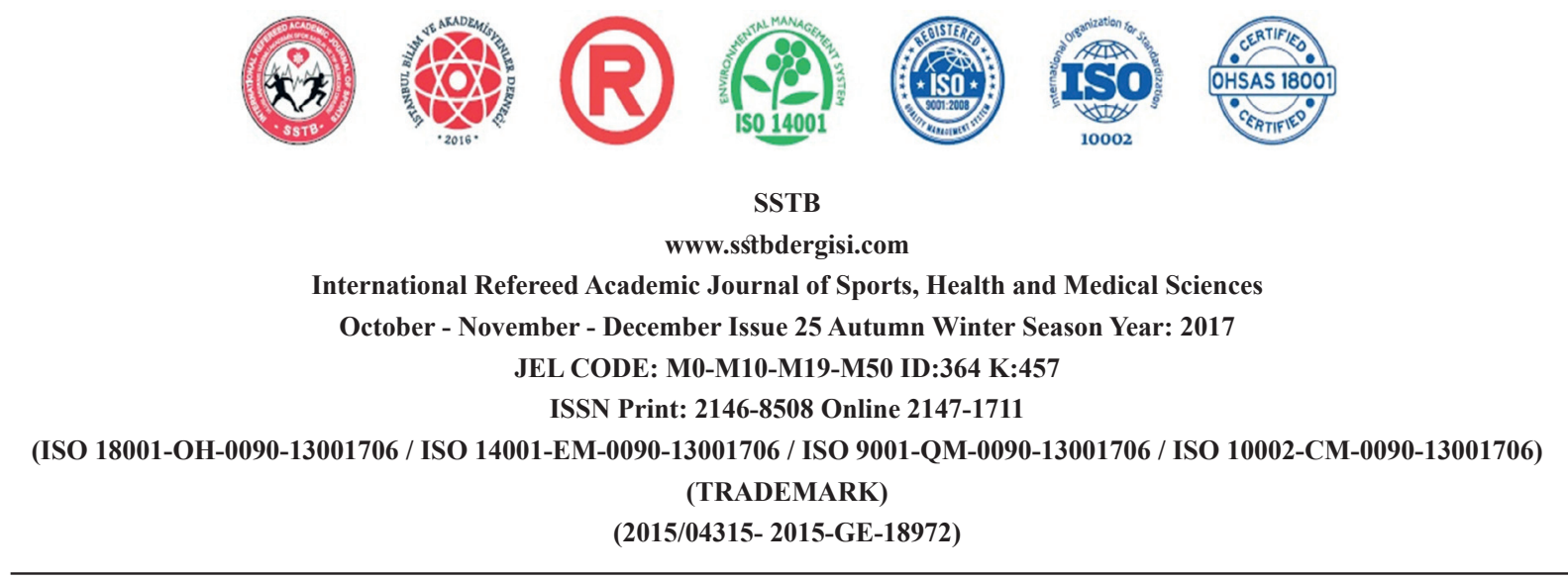

and mechanoreceptors. Due to their positive effects on the fascia and practical-economical aspects that can be used in every training environment, SMR with foam roller are widely used by the athletes to avoid injuries and enhance sportive performance.

\section{PURPOSE of STUDY}

Literature reviews indicate that the duration of SMR exercises vary between 10 seconds to 2 minutes (MacDonald et al., 2013: 815; Mikesky, et al., 2002: 449; Peacock et al., 2014: 205). However, in practice, 30 and 60 second exercises are most frequently applied.

The purpose of this study is to explore the impact of SMR exercises performed at different times on well-trained female volleyball players' vertical jump performance and lower extremity flexibility. The hypothesis of the study is that "foam roller exercises performed in 30 and 60 second sessions have different effects on lower extremity flexibility and vertical jump performance".

\section{MATERIAL and METHOD}

\section{Participants}

18 well-trained female volleyball players who signed a voluntary participation consent form took part in the study. Bioethical committee agreement for the research conduction was received the medical ethics committee of the medical faculty of the local university (protocol number: 19/16) in accordance with the Declaration of Helsinki. Participation criteria for the athletes are as follows: exercising regularly for the past three months, exercising for at least eight hours a week and not having experienced a lower extremity injury or surgical operation that would affect the test results. In addition, it was noted that they did not have any health problems like diabetes, epilepsy, neurological or neuromuscular disorder that would prevent their participation in the test protocols explained in the details of the study. The athletes were asked to avoid exhausting physical activities, not to consume food and drinks containing caffeine and similar stimulants and, also alcohol at least 24 hours before the test sessions.

\section{Study Design}

The athletes completed the study protocol in three different days with 48 hour intervals to avoid possible negative impacts such as physiological, neurophysiological factors and fatigue during the study. The research protocol used a randomized crossover study design involving control (CON), 30 second foam roller (FR30) and 60 second foam roller (FR60) exercise. The protocols were performed at the same time of day (13.00-15.00) to reduce the effects of circadian rhythm on the results of the study. The same foam roller equipment was used in the [exercise] sessions (The Vyper Hyperice, USA). To teach the technique 


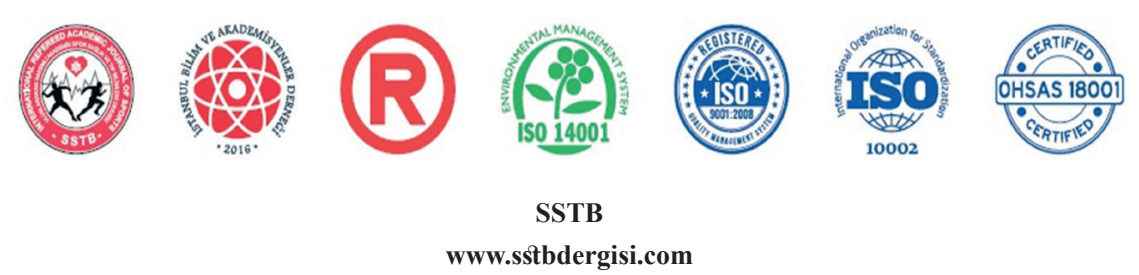

International Refereed Academic Journal of Sports, Health and Medical Sciences

October - November - December Issue 25 Autumn Winter Season Year: 2017

JEL CODE: M0-M10-M19-M50 ID:364 K:457

ISSN Print: 2146-8508 Online 2147-1711

(ISO 18001-OH-0090-13001706 / ISO 14001-EM-0090-13001706 / ISO 9001-QM-0090-13001706 / ISO 10002-CM-0090-13001706)

(TRADEMARK)

(2015/04315- 2015-GE-18972)

of foam roller exercises, all the athletes were provided training one week before starting the study.

\section{Warm-up Protocol}

In the study, the athletes performed a general warm-up on a peak bike (Monark Peak Bike, Sweden) with 74 watts $(1.5 \mathrm{~kg}, 50 \mathrm{rpm})$ for five minutes before all exercises.

\section{Control (CON)}

1 minute after completing the warm-up protocol, the athletes performed jumping test. 3 counter movement jump tests were performed with hands on the waist at fifteen second intervals. 30 second after the last jumping test, a 3 sit-and-reach flexibility test was performed with 15 second intervals, and the average of the values was recorded.

Foam Roller Exercise (FR30 - FR60)
1 minute after the standard warm-up protocol, $30 \mathrm{sec}$ foam roller exercise started. These exercises were bilaterally applied to hamstring, quadriceps, gluteal and calf muscle groups respectively (Figure 1) (Sağiroğlu, et al., 2017: 138). Both exercise sessions were performed in two sets with 30 second interval. During the performance, metronome was set to 40 bpm (Sağiroğlu, 2017: 25). 10 repetitions (rolling) were performed in 30 seconds in the FR30 session while 20 rolling exercises were performed in 60 seconds in the FR60 session. 1 minute after the exercises were completed, jumping test was performed. It was a 3 times counter movement jump test with hands on the waist with 15 second intervals. After 30 seconds from the last jumping test, a 3 sitand-reach test was performed with 15 second intervals, and the average of the values was recorded.

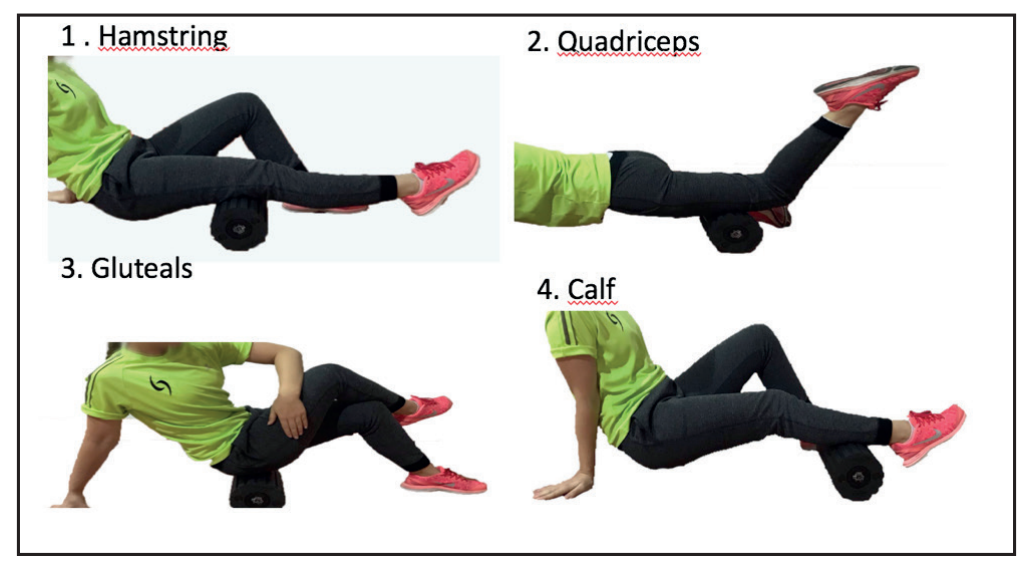

Figure 1. Foam roller exercises 


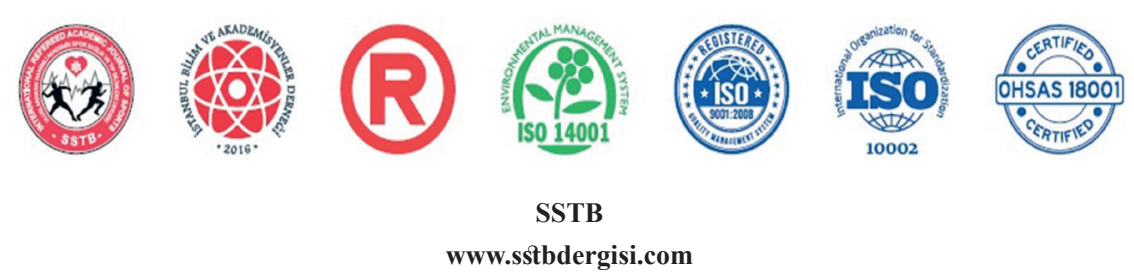

International Refereed Academic Journal of Sports, Health and Medical Sciences

October - November - December Issue 25 Autumn Winter Season Year: 2017

JEL CODE: M0-M10-M19-M50 ID:364 K:457

ISSN Print: 2146-8508 Online 2147-1711

(ISO 18001-OH-0090-13001706 / ISO 14001-EM-0090-13001706 / ISO 9001-QM-0090-13001706 / ISO 10002-CM-0090-13001706) (TRADEMARK)

(2015/04315- 2015-GE-18972)

Post-test flexibility values of the control, 30 second foam roller and 60 second foam roller exercises are indicated in Table 2. There was no statistically significant difference between the exercises.

Table 2. Post-Test Flexibility Values of the Control, 30 Second Foam Roller and 60 Second Foam Roller Exercises ( $\mathbf{N}=18)$

\begin{tabular}{|c|c|c|c|c|}
\hline & $\begin{array}{l}\text { Mean } \\
(\mathrm{cm})\end{array}$ & $\begin{array}{l}\text { S.D. } \\
\text { (cm) }\end{array}$ & $\mathrm{F}$ & $\mathrm{p}$ \\
\hline $\mathrm{CON}$ & 9,79 & 7,98 & \multirow[t]{3}{*}{0,060} & \multirow[t]{3}{*}{0,942} \\
\hline FR30 & 10,68 & 7,12 & & \\
\hline FR60 & 10,44 & 8,78 & & \\
\hline
\end{tabular}

Post-test vertical jump values of the control, was no statistically significant difference be30 second foam roller and 60 second foam tween the exercises.

roller exercises are indicated in Table 3. There

Table 3. Post-Test Vertical Jump Height Values of the Control, 30 Second Foam Roller and 60 Second Foam Roller Exercises $(\mathrm{N}=18)$

\begin{tabular}{|c|c|c|c|c|}
\hline & $\begin{array}{l}\text { Mean } \\
\text { (cm) }\end{array}$ & $\begin{array}{l}\text { S.D. } \\
\text { (cm) }\end{array}$ & $\mathrm{F}$ & $\mathrm{p}$ \\
\hline $\mathrm{CON}$ & 30,13 & 3,26 & \multirow[t]{3}{*}{0,468} & \multirow[t]{3}{*}{0,629} \\
\hline FR30 & 29,38 & 4,05 & & \\
\hline FR60 & 28,98 & 3,54 & & \\
\hline
\end{tabular}

Post-test vertical jump speed values of the control, 30 second foam roller and 60 second foam roller exercises are indicated in Table
4. There was no statistically significant difference between the exercises. 


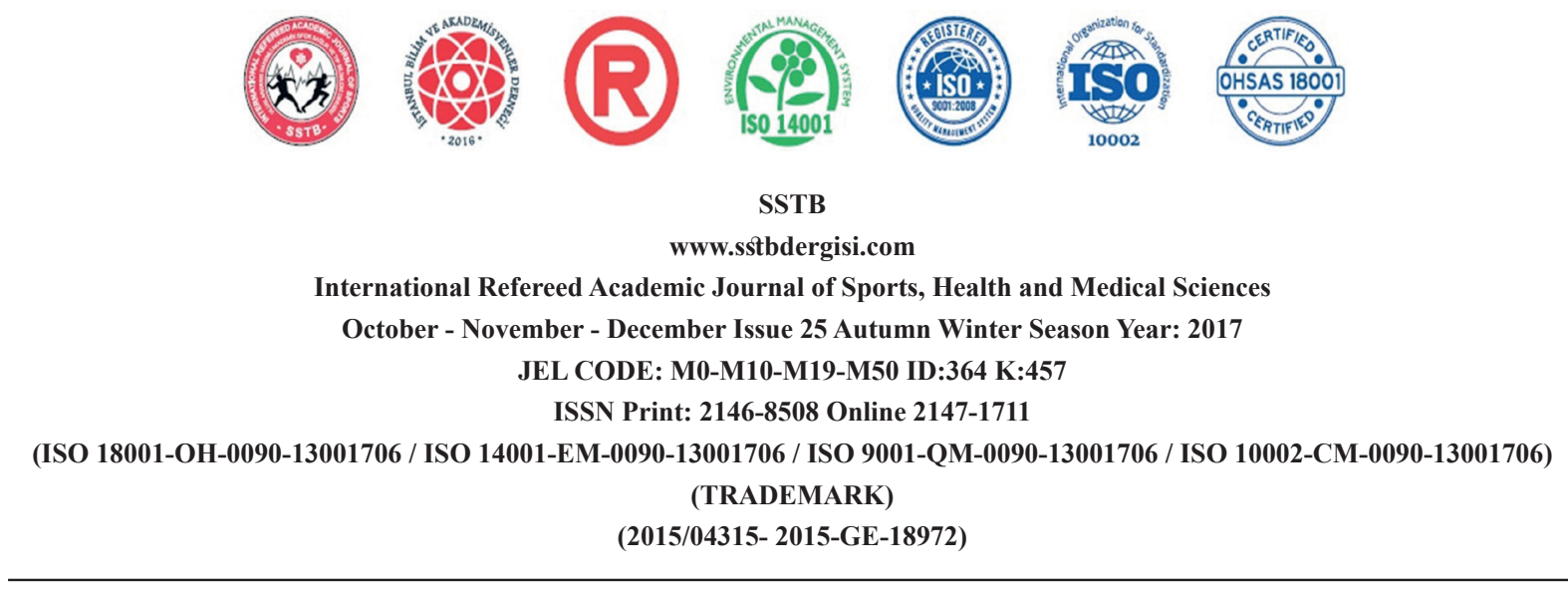

decline in power and strength performance as opposed to static stretching exercise while there is an increase in flexibility performance after foam roller exercises (Beardsley and Skarabot, 2015: 750, MacDonald et al., 2013: 818, Okamoto et al., 2014: 72, Peacock et al., 2015: 2314, Peacock et al., 2014: 210). In their study on 22 males, Jones, et al. (2015) found similar results for the effects of foam roller and dynamic stretching exercises on vertical jump performance and take-off velocity. Junker and Stöggl (2015) assigned 4-week foam roller exercise and proprioceptive neuromuscular facilitation (PNF) stretching exercise to 40 healthy males. At the end of the study, a similar improvement was found in hamstring flexibility in both exercise groups compared with the control group. They suggest that the increase in the flexibility performance after foam roller exercise may be due to a change in the thixotropic (liquid form) property of the fascia surrounding the muscle (Paolini, 2010). Fascia is composed of colloidal materials. When it is exposed to mechanical stress or heat with SMR exercises, it softens and becomes more fluid. When the stimulus disappears, it thickens again, its viscosity increases and it becomes stiffer (Lindsay and Robertson, 2008). Recent studies indicate that there is not a standard duration for SMR exercises, and it is proposed that the reason for obtaining contradictory results can be different exercise times preferred in the studies (Beardsley and Skarabot, 2015: 751; MacDonald et al., 2013: 814; Mikesky et al., 2002: 448; Peacock et al., 2014: 204; Sullivan and Silvey, 2013: 230). This study is the first to examine the effect of SMR exercises performed for different times (30 second and 60 second) on well-trained female volleyball players' vertical jump performance and lower extremity values.

When the results of the study were examined, similar to the studies in literature, no statistically significant difference was found in vertical jump performance between foam roller exercises and control exercise. However, as distinct from many studies, no statistically significant difference was found in flexibility performance as well between the control and foam roller exercises in the study. The reasons for this may be that the pressure applied to the fascia with foam roller may be insufficient or most of the subjects participating in the study did not have good lower extremity flexibility. Furthermore, the finding that both 30 second and 60 second SMR exercises do not have a negative effect on vertical jump and flexibility performance compared with the control group suggests that both times can be used by athletes. Thus, we can conclude that SMR exercises can be used as an alternative warm-up technique before competitions and training. 


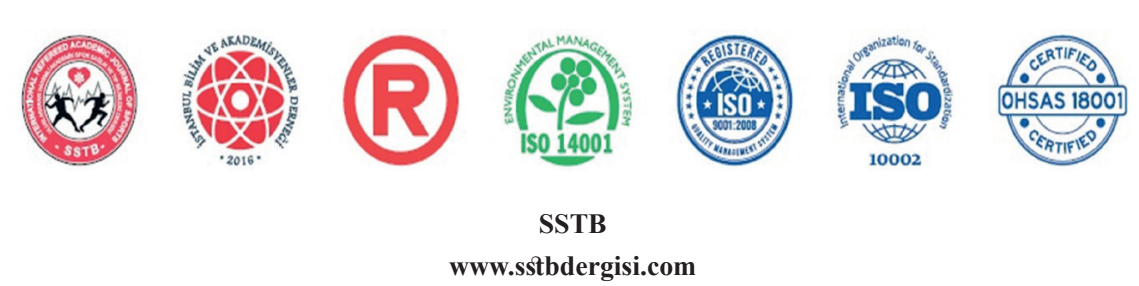

International Refereed Academic Journal of Sports, Health and Medical Sciences October - November - December Issue 25 Autumn Winter Season Year: 2017 JEL CODE: M0-M10-M19-M50 ID:364 K:457 ISSN Print: 2146-8508 Online 2147-1711

(ISO 18001-OH-0090-13001706 / ISO 14001-EM-0090-13001706 / ISO 9001-QM-0090-13001706 / ISO 10002-CM-0090-13001706) (TRADEMARK)

(2015/04315- 2015-GE-18972)

\section{REFERENCES}

BEARDSLEY, C., SKARABOT, J., (2015). Effects of self-myofascial release: A systematic review. J Bodyw Mov Ther, 19(4): 747-758. doi:10.1016/j. jbmt.2015.08.007

BECKETT, J.R., SCHNEIKER, K.T., WALLMAN, K.E., DAWSON, B.T., GUELFI, K.J., (2009). Effects of static stretching on repeated sprint and change of direction performance. Med Sci Sports Exerc, 41(2): 444-450. doi:10.1249/ MSS.0b013e3181867b95

BEHARA, B., JACOBSON, B.H., (2017). Acute Effects of Deep Tissue Foam Rolling and Dynamic Stretching on Muscular Strength, Power, and Flexibility in Division I Linemen. J Strength Cond Res, 31(4): 888-892. doi:10.1519/ JSC.0000000000001051

BEHM, D.G., CHAOUACHI, A., (2011). A review of the acute effects of static and dynamic stretching on performance. Eur J Appl Physiol, 111(11): ss.2633-2651. doi:10.1007/s00421-011-1879-2

BENJAMIN, M., (2009). The fascia of the limbs and back--a review. J Anat, 214(1): 1-18. doi:10.1111/j.14697580.2008.01011.x
CLARK, M., LUCETT, S., NATIONAL ACADEMY OF SPORTS MEDICINE. (2011). NASM's essentials of corrective exercise training (1st ed.). Philadelphia: Wolters Kluwer Health/Lippincott Williams \& Wilkins, ss: 78

CRAMER, J.T., HOUSH, T.J., JOHNSON, G.O., MILLER, J.M., COBURN, J.W., BECK, T.W. (2004). Acute effects of static stretching on peak torque in women. The Journal of Strength \& Conditioning Research, 18(2): 236-241

CURRAN, P.F., FIORE, R.D., CRISCO, J.J., (2008). A comparison of the pressure exerted on soft tissue by 2 myofascial rollers. J Sport Rehabil, 17(4): 432442

FAMA, B.J., BUETI, D.R., (2011). The Acute Effect Of Self-Myofascial Release On Lower Extremity Plyometric Performance. (Master of Science), Sacred Heart University, ss: 65

FRANCO, B.L., SIGNORELLI, G.R., TRAJANO, G.S., COSTA, P.B., DE OLIVEI$R A, C . G .$, (2012). Acute effects of three different stretching protocols on the Wingate test performance. J Sports Sci Med, 11(1): 1-7

HEALEY, K.C., HATFIELD, D.L., BLANPIED, P., DORFMAN, L.R., RIEBE, 
www.sstbdergisi.com

International Refereed Academic Journal of Sports, Health and Medical Sciences

October - November - December Issue 25 Autumn Winter Season Year: 2017

JEL CODE: M0-M10-M19-M50 ID:364 K:457

ISSN Print: 2146-8508 Online 2147-1711

(ISO 18001-OH-0090-13001706 / ISO 14001-EM-0090-13001706 / ISO 9001-QM-0090-13001706 / ISO 10002-CM-0090-13001706) (TRADEMARK)

(2015/04315- 2015-GE-18972)

Journal of Sports Physical Therapy, 8(3): 228-236

ACKNOWLEDGEMENTS: The funding source for this research was Unit of Scientific Research Projects, Trakya University (TÜBAP). There was no conflict of interest between Unit of Scientific Research Projects and the researchers. This study has been presented at "World Sports Sciences Research Congress," on 23-26 November 2017, in Manisa as an oral presentation. 